https://doi.org/10.15407/socium2021.02.079 UDC 303.71:[323.2:316.48](477+476)

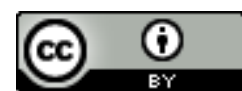

Creative Commons Attribution 4.0 International

Sheppental A.I., Post-graduate student, The Brandenburg University of Technology Cottbus-Senftenberg, 1, Platz der Deutschen Einheit, Cottbus, 03046, Germany, email: elmeit11@yahoo.de,ORCID iD: https://orcid.org/0000-0002-6439-1579

\title{
A MIXED-METHODS FRAMING ANALYSIS OF BELARUSIAN AND UKRAINIAN PROTESTS
}

The following study analysed online articles in German media discussing protests in Ukraine in 2014 and Belarussian protests in 2020. A mixed-methods approach of combining qualitative and quantitative content analyses was used to examine frames and frame sources utilised in the articles. There were 489 articles used for the analysis. The study also examined statistically significant differences between the frequency of frames by country. A frame indicated in each story was coded as a variable ("human impact", "powerlessness", "moral values", and "conflict"). The human impact frame was more common in articles regarding Belarus than in articles regarding Ukraine. The moral values frame was the least common frame in articles regarding both Ukraine and Belarus. The powerlessness frame was the most prominent for both countries. The most significant difference between the two countries was indicated regarding conflict frame utilisation. The statistical analysis shows that there is a statistically significant difference of frames covered by German media. The statistically significant difference of powerlessness frame was: 67,49\% (Ukraine) and 76,74\% (Belarus); in moral values frame: 2,48\% (Ukraine) and 6,59\% (Belarus); in the conflict frame: 24,46\% (Ukraine) and 6,59\% (Belarus); in human impact frame: 5,57\% (Ukraine) and 10,08\% (Belarus). Finally, the utilised sources by frame were indicated. Sources utilised for the powerlessness frame were international officials and local officials (in Ukraine and Belarus). Sources utilised for the human impact frame were citizens (in both Ukraine and Belarus) and oppositional politicians (Belarus only). Sources utilised for conflict frame: oppositional politicians (Ukraine only), international officials, local officials. Sources utilised for moral values frame were local celebrities, intellectual elite (Ukraine) and oppositional politicians (Belarus). Findings show that media in Germany relied mostly on politicians and international officials, while the perspective of ordinary citizens appeared to be less prominent.

Keywords: frame analysis, content analysis, news, Ukraine, Belarus.

Шеппенталь А.І., аспірант кафедри інтеркультурних відносин Бранденбурзького технологічного університету Котбус-Зенфтенберг, вул. Еріх-Вайнерт, 1, Котбус, 03046, Hiмеччина, email: elmeit11@yahoo.de, ORCID iD: https://orcid.org/0000-0002-6439-1579

\section{АНАЛІЗ ФРЕЙМІВ РЕЗУЛЬТАТІВ ДОСЛІДЖЕННЯ БІЛОРУСЬКИХ І УКРАЇНСЬКИХ ПРОТЕСТІВ 3 ВИКОРИСТАННЯМ ЗМІШАНИХ МЕТОДІВ}

Проаналізовано статті в німецьких онлайн-ЗМI, які висвітлювали протести в Україні у 2013-2014 рр. та Білорусі у 2020 р. Для ідентифікації фреймів, а також їх джерел, використаних у статтях, застосовано підхід змішаного методу. Загальний розмір вибірки склав 489 статей. Розглянуто статистично значущі відмінності частоти фреймів між

(C) Sheppental A.I., 2021

ISSN 1681-116X. Ukrainian Society, 2021, № 2 (77): 79-94 


\begin{abstract}
краӥнами. Фрейм, зазначений у кожній статі, кодувався як “людський вплив”, “безсилля”, “моральні иінності” та “конфлікт”. Фрейм “людський вплив” був більи поширеним у стат. тях стосовно Білорусі. Фрейм “моральні цінності” був найменш поширеним стосовно обох краӥн. Фрейм “безсилля” був найпоширенішим в обох випадках. Найсуттєвіша різниия між двома країнами була ідентифікована щодо фрейму “конфлікт“. Статистичний аналіз виявив статистично значущу відмінність між частотою фреймів, використаних німецькими ЗмІ. Статистично значуща різниия фрейму “безсилля” становить 67,49\% (Україна) та 76,74\% (Білорусь). Статистично значуща різниця фрейму “моральні цінності" становить 2,48\% (Україна) та 6,59\% (Білорусь). Статистично значуща різничя фрейму “конфлікт” становить 24,46\% (Україна) та 6,59\% (Білорусь). Статистично значущза різниия фрейму “людський вплив” становить 5,57\% (Украӥна) та 10,08\% (Білорусь). Ідентифіковано джерела фреймів. Джерелами фрейму “безсилля” були міжнародні та місцеві чиновники (у статтях стосовно України та Білорусі). Джерелами фрейму “людський вплив” були громадяни (як в Украӥні, так $i$ в Білорусі) та опозиційні політики (лише в Білорусі). Джерела фрейму “конфлікт” - опозиційні політики (лише Украӥна), міжнародні чиновники, місцеві чиновники. Джерелами, щьо використовувались для фрейму “моральні изінності”, були місцеві лідери громадської думки, інтелектуальна еліта (Украӥна) та опозииійні політики (Білорусь). Підсумовано, щуо засоби масової інформачії в Німеччині переважно посилались на політиків і міжнародних чиновників.
\end{abstract}

Ключові слова: аналіз фреймів, контент-аналіз, новини, Украӥна, Білорусь.

Due to the emerging number of peaceful political demonstrations, non-violent resistance receives more attention in both the media and academic areas. This study's objective is to analyse differences in utilised frames in German media articles regarding Ukrainian protests, which happened between 2013 and 2014 and recent Belarussian protests.

Political and social changes (also known as the Revolution of Dignity) in Ukraine from November 30, 2013, to February 2014, were caused by the protest of Ukrainian citizens against the illegal riot police violence towards a peaceful action of students and civic activists, which began on November 21, 2013, as a resistance to the departure of the country's political leadership. One of the main reasons for the protests was the excessive concentration of power in the hands of Viktor Yanukovych and the unwillingness of the people of Ukraine to accept the transformation of the country ${ }^{1}$.

Protest actions in Belarus began in May 2020. This was due to the preparations for the next presidential elections, which were held on August 9. From that day on, the one-off protest acquired a nationwide scale, the situation in the country began to be characterised as a political crisis $^{2}$.

1 A timeline of the Euromaidan revolution. (2016, February 20). Euromaidan Press. http://euromaidanpress.com/2016/02/19/a-timeline-of-the-euromaidan-revolution/; Chronology of injustice in EuroMaidan investigations. (2020, Februar 8). Kyiv Post. URL: https://www.kyivpost.com/ukrainepolitics/chronology-of-injustice-in-euromaidan-investigations.html; Dearden, L. (2014, September 2). Ukraine crisis: A timeline of the conflict from the Euromaidan protests to MH17 and civil war in the east. The Independent. URL: https://www.independent.co.uk/news/world/europe/ukraine-crisis-timeline-conflicteuromaidan-protests-mh17-and-civil-war-east-9706999.html

2 Timeline of election turmoil in Belarus. (2020, August 11). RTE.ie. URL: https://www.rte.ie/news/newslens/2020/0811/1158602-belarus/ 
Mass protests throughout Belarus unfolded on election day, immediately after the closure of polling stations and the announcement of preliminary voting results. The protesters accused the authorities of falsifying the election results in favour of the incumbent President Alexander Lukashenko. During the clashes between some of the protesters and law enforcement officers, the police used tear gas, stun grenades, water cannons, and rubber bullets, which were justified by provocations and violations according to law enforcement agencies' representatives public order by the demonstrators ${ }^{3}$.

Both occurrences happened in former USSR countries with similar historical and cultural backgrounds. On the other hand, the non-identical outcome of both resistance movements and different international responses are significant differential factors. Apart from that, there is a seven-year gap between the two events, which may provide an opportunity to estimate the possible changes in the representation of Eastern European politics in German media throughout the past years.

The main purpose of the following study is to evaluate the media representation of protests in Belarus and Ukraine and its potential impact on German society. In this study, a frame analysis method was chosen. Frame analysis "is regarded as one of the dominant techniques for investigating newspaper discourse as it mainly is used to analyse how people understand, perceive, comprehend situations and communication” [1, p. 133]. A primary function of media frames is to affect the understanding of the news by potential recipients. Even though the utilisation of the specific media frames cannot determine the particular political position [2], the presentation of news in mass media can systematically affect how the audience understands specific issues. Therefore, a frame analysis provides an opportunity to analyse the evaluation of Belarussian and Ukrainian protests in German media and an impression of the potential audience, which journalists attempted to create.

Otherwise, two crucial aspects of protest framing must be considered. The first aspect refers to a general approach to the political resistance of German journalists. As stated by some media researchers [3-6], journalists tend to trivialise the aims and purposes of the resistance movement and reinterpret them per their own political beliefs.

The second aspect refers to the possible change of representation of Eastern European politics in German media and their reception of former USSR countries politics. In this regard, a particularly interesting question that framing analysis may answer is the evaluation of protest movements in both countries in terms of a possible change of German perspective on Eastern European politics within the past seven years.

Media Frames. Framing is a theoretical approach, which has been widely used in media studies. Framing theory is based on the assumption that any topic can be interpreted differently. Framing theory has been widely influenced by postmodernist tradition, or more precisely, media semiotics. According to Fourie, who analysed connections of framing theory with media semiotics: There are many examples of various kinds of codes operational in media texts, beginning with clear distinctions between codes of form and codes of content and moving on from there to the analyses of codes of behaviour, analogue and digital codes,

\footnotetext{
${ }^{3}$ Hrydzin, U. (2020, Mai 25). Belarusians Protest Against Lukashenka's Run For Sixth Term As President. RadioFreeEurope/RadioLiberty. URL: https://www.rferl.org/a/belarus-protests-politcs/30632716.html
} 
presentational and representational codes, elaborated and restricted codes, and logical, aesthetic and social codes [7]. There is no generally acceptable unified definition of Framing. Chong and Druckman emphasise that framing can be described both as a process of a conceptualisation of a specific topic and a process that aims to change perspective regarding certain events of problematic issues [8]. Goffman is one of the most prominent theorists who defined and formulated a frame concept. Goffman states that we use certain frames to signify the schemata of representation, allowing us to identify, interpret, or label particular issues or events.

Goffman describes two types of frameworks:

Natural frameworks - which can be described as undirected, unanimated, unguided, purely physical. They do not presuppose any willful agency or actor who guides the outcome, as well as no negative or positive sanctions. An example of this kind of frame could be a weather report.

Social frameworks imply background understanding for events that will aim and control intelligence efforts, a live agency. What this does can be described as guided doings. An example - the newscast reporting of the weather. Social frameworks represent deeds and not events.

Goffman stated that even though we tend to interpret natural events as occurrences, which are entirely independent of any kind of intelligent intervention, intelligence and being performed as "entrances into natural order" [9, p. 23]. Therefore, any socially guided doing can be partly interpreted following a natural schema.

Guided doings appear to have two kinds of understanding:

1. One pertains to the patent manipulation of the natural world under the particular constraints that natural occurring's impose.

2. The other pertains to the particular worlds in which the actor can become involved, which, of course, vary considerably two bases for guidance - physical management of the vehicle, not the sign or social world of opposing positions, where a move can be made by voice, gesture or mails [9, p. 23-25].

Reese attempted to formulate the following definition of frames: Frames are organising principles that are socially shared and persistent over time, that work symbolically to structure the social world meaningfully:

Organising: Framing varies in how successfully, comprehensively, or thoroughly it organises information.

Principles: The frame is based on an abstract principle and is not the same as the texts through which it manifests itself.

Shared: The frame must be shared on some level for it to be significant and communicable.

Persistent: The significance of frames lies in their durability and their persistent and routine use over time.

Symbolically: The frame is revealed in symbolic forms of expression.

Structure: Frames are organised by providing identifiable patterns or structures varying in complexity [10, p. 11]. 
News frames have always been a relatively common subject of analysis within frame theory. Despite ideals of neutrality and objectiveness, the news does not represent reality but instead aims to induce a specific understanding of a particular event.

Terkildsen and Schnell claim that framing is important whenever an issue can be presented in multiple ways, potentially influencing how people think about an issue [11, p. 881]. Kahneman \& Tversky claim that framing is a deliberate selection of representation elements, purposely influencing recipients' opinions, insights or decisions [12]. Tod Gitlin was one of the first social scientists to investigate media frames. In "The whole world is watching", he analysed American media coverage of the New Left movement in the 1960s. He claimed that journalists in mainstream media tend to control the general public's perception of activism, perpetuating specific images and understandings of any political movements [6]. They generally would undermine and trivialise any kind of statements and messages that political movements try to present and discourage potential supporters. In the New Left movement, which Gitlin analysed, activists were represented as those who just deal with single consequences of systems problems instead of making a fundamental impact. Journalists undermined Students' effort for a Democratic Society (SDS) and stated that they do not represent a coherent political opposition. Instead, they focused on less significant issues without a real effort of changing the systematic errors and global social relations and, therefore, became pointless [6].

A more recent example of trivialising an oppositional movements political agenda is an Occupy Wall Street movement. According to M. Bray, who was one of the active participants of this movement, there was a massive confusion among journalists as to how they should represent the OWS movement and "paradoxically, their insights stemmed from their confusion" [5, p. 25]. There were two kinds of strategies journalists used to adopt. They either intentionally induced a particular understanding aiming to misinterpret the agenda of the OWS-movement, demonstrating their political bias, or they failed to interpret the OWS and its statement, unconsciously representing a particular cliché, which was common in an American political scene. Bray claims that many journalists in American mainstream media, despite having a deliberate intention to understand the core aims of the OWS movement, simply fell into usual narratives [5].

Pan and Kosicki proposed an interesting approach to the news framing process. They claim that "news discourse is conceived as a sociocognitive process involving all three players: sources, journalists, and audience members operating in the universe of shared culture and based on socially defined roles" [13, p. 55]. This interpretation of the framing process indicates its complexity and the importance of consideration of multiple aspects (such as sources or variable contexts) in frame theory.

Sources. In this study, a researcher refers to the term "source" to refer to the persons whom journalists turn to obtain information for stories [3, p. 102]. There are several approaches in media studies to describe a relationship between a reporter and his source. Some researchers battle for power over public opinion and public consent [3; 14]. However, according to Berkowitz, the interaction between these two parties represents a long-term yet dynamic influence on society: the ability to shape ongoing meanings in culture [3, p. 102]. 
Another important topic in media-source related studies is a source of credibility. As Hovland and Weiss claim, "communications from sources considered by subjects to be "trustworthy" were found to be significantly more effective in changing opinion in the direction advocated by the communicator than were identical communications attributed to sources considered "untrustworthy" when opinion change was measured immediately after communication" [15].

The problematic aspect of this notion might be, however, that if reporters tend only to select government officials, widely known politicians and other prominent public figures, they tend to appear more credible while at the same time perpetuating a relatively one-sided and possibly biased insight on the topic.

When it comes to international journalism, "press systems and political systems both vary across regions and countries, as does the social status of journalists, so what might appear to a Western perspective as co-optation, just as likely reflects the pragmatics of journalistic and, more broadly, cultural realities" [3, p. 102]. This is an important problem in the case of this particular study.

Research design. In the current study, a researcher opted for a mixed-method design. As Almalki states: "the use of different approaches has the potential to provide a greater depth and breadth of information which is not possible utilising singular approaches in isolation" [16, p. 288].

Schoonenboom and Johnson outline an important distinction when designing a mixedmethods study relates to the timing of the two (or more) components: "In a sequential design, the quantitative component precedes the qualitative component or vice versa. In a contemporary design, both components are executed (almost) simultaneously" [17]. In the current study, the qualitative component will be executed before quantitative analysis so that the design can be described as sequential.

Dependence represents the second aspect of timing. The research design can be described as a dependent when the implementation of the second component relies on the results of data analysis in the first component. If their implementation of one component does not depend on the results of data analysis in the other component, they can be described as independent [18].

In this study, the results of quantitative analysis are dependent on data collected during the first stage. According to Creswell and Plano Clark, this design can be described as exploratory sequential (the quantitative analysis follows a qualitative data collection to test the qualitative results) [19].

A mixed-methods study has at least one point of interface typically. Morse and Niehaus identify two possible points of interface: the results point of interface and the analytical point of the interface [19]. In the case of an analytical point of integration, a first stage represents a qualitative analysis is followed by a second stage, in which the results obtained during the qualitative analysis are being statistically analysed [19]

The following study represents a qualitative analysis of online news stories, while the frames utilised in those stories will be indicated. A second stage represents the statistical analysis of data collected during the first stage. In this case, a point of the interface can be described as analytical. 
Purpose and research questions. Bryman suggests that purposes of mixed-methods research include:

Offset - refers to the suggestion that the research methods associated with both quantitative and qualitative research have their strengths and weaknesses, so that combining them allows the researcher to offset their weaknesses to draw on the strengths of both.

Completeness - refers to the notion that the researcher can bring together a more comprehensive account of the area of enquiry in which he or she is interested if both quantitative and qualitative research are employed.

Credibility - refers to suggestions that employing both approaches enhances the integrity of findings.

Utility or improving the usefulness of findings - refers to a suggestion, which is more likely to be prominent among articles with an applied focus, that combining the two approaches will be more helpful to practitioners and others.

Confirm and discover - this entails using qualitative data to generate hypotheses and quantitative research to test them within a single project.

Sampling - refers to situations in which one approach is used to facilitate the sampling of respondents or cases.

Utility or improving the usefulness of findings - refers to a suggestion, which is more likely to be prominent among articles with an applied focus, that combining the two approaches will be more helpful to practitioners and others [20, p. 106].

In this study, a mixed-methods approach was opted due to the higher credibility of results comparing to qualitative frame analysis. Apart from combining both approaches, a researcher seeks to achieve more comprehensive results regarding the enquiry. Finally, a researcher believes that a mixed-methods approach can lead to a higher degree of usefulness of the study's results.

Following research questions will be answered in this study:

RQ1: How did German media frame protests in Belarus and Ukraine, and which are the most prominent frames utilised?

RQ2: Are there statistically significant differences between the frequency of frames utilised in online journal articles?

RQ3: What sources are utilised, and with what frames are they associated?

RQ4: How did the news stories analysed in this study influence German officials' and the general public's opinions?

Sampling. A total of 489 online articles were analysed. The time frame opted by a researcher was 90 days in each case, starting from the first day of protest in each country (August 9, 2020, in Belarus and November 30, 2014, in Ukraine). For the study analysis, 55 days were selected randomly using a random number generator (random.org). Considering that this particular study is a media representation of foreign countries in German media, avoiding any bias was a significant challenge. As already mentioned, because of an overall tendency for journalists to trivialise and unobjectively represent political resistance even in their own country, covering protests in foreign countries without a grounded knowledge of the local political scene has even more bias potential. Because of that, online media with different political sympathies were chosen: 
Zeit.de - The weekly newspaper Die Zeit is one of the few German print media that has increased circulation in recent years. Die Zeit cultivates the debate and often contrasts opinions with different positions or works out different opinions in the article series. There are regional editions for Austria, Switzerland, and Hamburg city.

Spiegel - Spiegel Online was one of the news portals with the most significant reach in Germany. It was founded editorially independently of the parent journal Der Spiegel.

Süddeutsche Zeitung - The Süddeutsche Zeitung is the largest German national subscription daily newspaper. As one of the first high-quality newspapers, the SZ closed the comment under the online articles in September 2014 and set up an opinion forum to ward off unqualified comments.

Frankfurter Allgemeine - The Frankfurter Allgemeine Zeitung is published by a GmbH, 93,7 per cent of which is owned by the Fazit Foundation. It is directed by an editorial board, which also determines the line of the paper. Until 2007, the FAZ kept its conservative appearance with Fraktur headings and no coloured cover picture ${ }^{4}$.

Coding scheme. Four frames were predefined based on a frame list initially proposed by Neuman, Just and Crigler [2]. They identified five frames, which are commonly utilised in news media:

- the human impact frame focuses on "descriptions of individuals and groups affected by an issue";

- the powerlessness frame refers to "the dominance of forces over weak individuals or groups";

- the economics frame reflects "the preoccupation with profit and loss";

- the moral values frame refers to "morality and social prescriptions";

- the conflict frame deals with the news media's "game interpretation of the political world as an ongoing series of contests, each with a new set of winners and losers".

Initially, an economic frame was included. The decision not to consider it in this particular study was made after analysing the sample. The reason for this was almost a complete absence of this particular frame indicated after the analysis of all 489 articles.

A frame indicated in each story was coded as a variable ("human impact", "powerlessness", "moral values", and "conflict"). Human impact refers to stories where the personal impact of protest participants was covered. In this case, participants were represented as actors whose actions can make a difference instead of the generalised view of protesters. Powerlessness is related to any condition, where either local or international officials are represented as those who have a dominant role in contrast to protest groups. For instance, a dominant influence of local or foreign authoritarian regimes and their communication with international officials would indicate a particular focus of German media while covering protests in both countries. Moral values stand for the ethical evaluation of issues covered in media, while the issues covered in news stories are represented in a more empathic manner. Conflict frame refers to any issues relating to conflicts between protesters and local government. An exceptionally important in this regard is a comparison

\footnotetext{
${ }^{4}$ Europe's media at a glance. (2020). Eurotopics.net. URL: https://www.eurotopics.net/de/142186/medien [in German]
} 
between frequencies of powerlessness and human impact frames. A prevalence of the human impact frame would indicate a more empathic attitude towards regular protesters [2]. In contrast, a prevalence of powerlessness frame would indicate a focus on negotiations between elites and counter-elites (in this case, an impact of protesters is likely to be trivialised). Each article was analysed to 1) common themes in news coverage of protests in Belarus and Ukraine; 2) sources of direct and paraphrased quotations; 3) dominant frames used to explain events and related political discussion.

Inter-coder reliability. According to K.A. Neuendorf [21, p. 8], coder training is an essential part of all human-coded content analyses. To test the reliability of the coding system, two coders were additionally trained. Each coder was given 15 per cent of the sample. The inter-coder reliability was 0,89 using Cohen kappa.

Results. The analysis of 489 online articles in German media regarding Ukrainian protests in 2013-2014 and recent Belarussian protests will be represented. The researcher first reports on the most prominent frames using a coding scheme proposed by Neuman, Just and Crigler (RQ1), then the statistically significant differences of frames indicated during online article analysis will be represented (RQ2). After that, sources used in the analysed articles used by German media for both Ukrainian and Belarussian events will be represented (RQ3).

Tables 1 and 2 summarise frequencies of the frames by country in different German online media.

Table 1

Frames utilised in articles on Belarussian protests by media

\begin{tabular}{|l|c|c|c|c|c|c|c|c|c|c|}
\multicolumn{1}{l|}{} & Zeit & $\%$ & Spiegel & $\%$ & FAZ & $\%$ & $\begin{array}{c}\text { Süddeutsche } \\
\text { Zeitung }\end{array}$ & $\%$ & $\begin{array}{c}\text { Total frames by } \\
\text { country }\end{array}$ & $\%$ \\
\hline $\begin{array}{l}\text { Powerlessness } \\
\text { frame }\end{array}$ & 51 & 41,13 & 51 & 73,91 & 27 & 79,41 & 69 & 79,31 & 198 & 77,95 \\
\hline $\begin{array}{l}\text { Moral values } \\
\text { frame }\end{array}$ & 3 & 2,42 & 4 & 5,8 & 3 & 8,82 & 3 & 3,45 & 13 & 5,12 \\
\hline Conflict frame & 1 & 0,81 & 9 & 13,04 & 2 & 5,88 & 5 & 5,75 & 17 & 6,69 \\
\hline $\begin{array}{l}\text { Human impact } \\
\text { frame }\end{array}$ & 9 & 7,26 & 5 & 7,25 & 2 & 5,88 & 10 & 11,49 & 26 & 10,24 \\
\hline Total (100\%) & 124 & 100 & 69 & 100 & 34 & 100 & 87 & 100 & 254 & 100 \\
\hline
\end{tabular}

Source: own research.

Table 2

Frames utilised in articles on Ukrainian protests by media

\begin{tabular}{|l|c|c|c|c|c|c|c|c|c|c|}
\cline { 2 - 12 } \multicolumn{1}{c|}{} & Zeit & $\%$ & Spiegel & $\%$ & FAZ & $\%$ & $\begin{array}{c}\text { Süddeutsche } \\
\text { Zeitung }\end{array}$ & $\%$ & $\begin{array}{c}\text { Total frames } \\
\text { by country }\end{array}$ & $\%$ \\
\hline Powerlessness frame & 44 & 69,84 & 97 & 66,9 & 18 & 52,94 & 59 & 72,84 & 218 & 67,49 \\
\hline Moral values frame & 3 & 4,76 & 2 & 1,38 & 2 & 5,88 & 1 & 1,23 & 8 & 2,48 \\
\hline Conflict frame & 12 & 19,05 & 36 & 24,83 & 13 & 38,24 & 18 & 22,22 & 79 & 24,46 \\
\hline Human impact frame & 4 & 6,35 & 10 & 6,9 & 1 & 2,94 & 3 & 3,7 & 18 & 5,57 \\
\hline Total (100\%) & 63 & 100 & 145 & 100 & 34 & 100 & 81 & 100 & 323 & 100 \\
\hline
\end{tabular}

Source: own research. 
The most prominent frame in both countries was the powerlessness frame. Nevertheless, we can indicate a slight difference between Ukraine $(\mathrm{N}=218)$ and Belarus $(\mathrm{N}=198)$. The human impact frame was slightly more common in articles regarding Belarus $(\mathrm{N}=26)$ than in articles regarding Ukraine $(\mathrm{N}=18)$. The moral values frame was also the least common one appearing in articles regarding Ukraine $(\mathrm{N}=8)$ and Belarus $(\mathrm{N}=13)$. Finally, the most significant difference was indicated regarding conflict frame, while in Ukraine, it was indicated in 79 articles; in Belarus, conflict frame was only indicated in 17 articles.

Research question $\mathbf{2}$ asks if there is a statistically significant difference of frames covered by German media during the protest-regarded reports. In order to decide whether it is preferred to use Fisher's Exact Test, the literature suggests looking at the contingency table [22]. If one of the expected values in that contingency table is less than 5, Fisher's Exact Test is preferred (which means that the sample size is not sufficiently large) [23]. Since the table does not indicate values $<5$, the researcher decided to test the null hypothesis using the Chi-square test:

- the null hypothesis of the Chi-square test claims that the variables are independent and there is no relationship between the two categorical variables. Knowing the value of one variable does not help to predict the value of the other variable;

- the alternative hypothesis assumes that the variables are dependent and that there is a relationship between the two categorical variables. Knowing the value of one variable helps to predict the value of the other variable.

After conducting the Chi-square test its associated $\mathrm{p}$-value is $\mathrm{p}<0,01$ ( $\mathrm{X}$-squared $=35,91, \mathrm{df}=3, \mathrm{p}<0,01)$, which means the null hypothesis can be rejected. The given frames indicate an association between the two groups (indicating statistically significant results). Additionally, a Bayesian test of association was conducted. Analyses were conducted using the BayesFactor package Ver. 0.9.12.4.2 in $\mathrm{R}$ using a Poisson sampling plan. A test of association produced a Bayes factor of $1007127 \pm 0 \%$ favouring a relationship between the two groups [24, p. 104-106].

Table 3 shows the statistically significant difference of frames covered by German media in two different countries.

Table 3

The statistically significant difference of frames by country, by county, $\%$

\begin{tabular}{|l|c|c|}
\hline \multicolumn{1}{|c|}{ Frame } & Ukraine & Belarus \\
\hline Powerlessness & 218 & 198 \\
\hline$\%$ & 67,49 & 77,95 \\
\hline Moral values & 8 & 13 \\
\hline$\%$ & 2,48 & 5,12 \\
\hline Conflict & 79 & 17 \\
\hline$\%$ & 24,46 & 6,69 \\
\hline Human Impact & 18 & 26 \\
\hline$\%$ & 5,57 & 10,24 \\
\hline Total & 323 & 254 \\
\hline
\end{tabular}

Source: own research. 
Interpretation. The statistically significant difference of powerlessness frame was the most prominent frame: $67,49 \%$ (Ukraine) and 76,74\% (Belarus). The prevalence of the powerlessness frame indicates a focus on negotiations between local political elites and international officials (represented mainly through Russian and German politicians). However, there is an almost $10 \%$ difference between the frequency of this frame in both countries. This means that German media were more likely to emphasise the influence of the political elites on the protest outcome in articles regarding Belarus. Apart from that, the image of Lukashenko as a powerful dictator in contrast with protesters, which were represented as helpless victims, was a standard narrative.

The statistically significant difference in the conflict frame: $24,46 \%$ (Ukraine) and $6,59 \%$ (Belarus). Conflict frame was more prevalent in $17,87 \%$ of cases in articles regarding Ukraine. The possible reason for this is a change of protest dynamics in Ukraine after repeated incidents of violence on Maidan square, whilst there was a growing number of clashes between protesters and the police.

The statistically significant difference in the human impact frame: 5,57\% (Ukraine) and $10,08 \%$ (Belarus). As stated above, a prevalence of the human impact frame would indicate an empathic attitude towards protesters and interest in their perspective. In both cases, a human impact frame was less frequent than a powerlessness frame. However, this frame was more frequently utilised in articles regarding Belarus. The reason for this appears to be a different strategy of Belarusian protesters, who decided to avoid direct clashes with the police, despite quite frequent cases of police brutality. According to Stephan and Chenoweth [21], non-violent protests are more likely to gain greater external support because "potentially sympathetic publics perceive violent militants as having maximalist or extremist goals beyond accommodation" [25, p. 9].

The statistically significant difference in moral values frame: 2,48\% (Ukraine) and $6,59 \%$ (Belarus). The moral values frame represents an ethical evaluation of issues covered in media. In both cases, this frame was least frequent, implying that German media tended to set aside the ethical aspect of resistance movements in both countries.

Research question 3 asks What sources are utilised and with what frames are they associated with? Table 4 displays the sources used in each of the four identified frames.

Sources by country

\begin{tabular}{|l|l|l|}
\hline \multicolumn{1}{|c|}{ Frame } & \multicolumn{1}{|c|}{ Sources Ukraine } & \multicolumn{1}{c|}{ Sources Belarus } \\
\hline Powerlessness Frame & International officials, local officials & International officials, local officials \\
\hline Human Impact Frame & Citizens & Oppositional politicians, citizens \\
\hline Conflict Frame & $\begin{array}{l}\text { Oppositional politicians, international } \\
\text { officials, local officials }\end{array}$ & International officials, local officials \\
\hline Moral Values & Local celebrities, intellectual elite & $\begin{array}{l}\text { Oppositional politicians, intellectual } \\
\text { elite }\end{array}$ \\
\hline
\end{tabular}

Source: own research.

Interpretation. The results show that sources used while utilising the most frequent powerlessness frame were international and local officials in both countries. Regarding articles where the human impact frame was utilised, journalists relied on different sources. In 
news stories regarding Belarus, oppositional politicians were used as a source, which was not the case in Ukraine. The usage of oppositional politicians as a source was different depending on the country. Sources used in articles where conflict frame was utilised look similar, except that only in articles about Ukraine the oppositional politicians were used as a source.

Another prominent tendency indicated by the researcher is that citizens were used as a source only in case of human impact frame. On the other hand, only in Belarus, oppositional politicians appeared as sources in stories where moral values were framed. While Ukrainian oppositional leaders were represented as those who seek political power and authority, Belarusian oppositional politicians were described as average citizens who became engaged in politics due to unforeseen circumstances (as it was in the case of Tichanowskaja). Thus, the point of view of average citizens appeared to be less relevant for German journalists.

Despite a seven-year gap between protests in Ukraine and Belarus, there is one distinct tendency, which the researcher indicated. The most frequent frame in both cases was the powerlessness frame. Powerlessness frame sources were represented by local and international authorities, while citizens were only represented in articles where the human impact frame was utilised. This means that most articles used politicians as sources, leading to unbalanced and biased representation [15]. German media tend to describe both occurrences regarding international power dynamics and negotiations between Russian and German officials while neglecting the point of view of casual protesters.

Research question 4 asks: how did the news stories analysed in this study influence German officials and the general public's opinion?

To answer the Research question 4, the media credibility of German media should be taken into account. According to the survey on the credibility of individual media in Germany 2020, 52\% of Germans evaluate the information obtained from news media as trustworthy ${ }^{5}$, which indicates that news media have a potentially significant influence on the half of German population. Regarding the potential political influence of the news stories chosen in this study, a few issues should be considered. The impact of the particular parties in German politics remains relatively stable over the last 10 years. There are two major political parties in Germany: the CDU and the SPD (even though neither can achieve a parliamentary majority in an election) ${ }^{6}$. Their political position can be described as Centreright. In the 2017 German federal elections, a far-right political party AfD won 12,6\% of the vote and received 94 seats in Bundestag ${ }^{7}$. The growing popularity of AfD is typically associated with their Eurosceptic and anti-migration policy [26]. However, according to Schärdel, "since its establishment in 2013, the German political party Alternative für

\footnotetext{
5 Media credibility survey by 2021. (2021, Mai 10). Statista. URL: https://de.statista.com/statistik/daten/studie/794879/umfrage/glaubwuerdigkeit-der-medien-in-west-undostdeutschland/ [in German]

6 Bundeswahlleiter, D. (2017). Results Germany - The Federal Returning Officer. URL: https://web.archive.org/web/20171124142346/https://www.bundeswahlleiter.de/bundestagswahlen/2017/er gebnisse/bund-99.html [in German]

The same.
} 
Deutschland (AfD) has had an exceedingly strained relationship with the media" [27] and thus is underrepresented in German media. Apart from that, AfD is known for its pro-Russian position ${ }^{8}[26 ; 28]$.

On the other hand, mainstream German media represents political positions, which tend to be closer to most influential German parties (a percentage of supporters of CDU and SPD altogether $53 \%{ }^{9}$ corresponds with the percentage of the population finding German news media a trustworthy source of information ${ }^{10}$ ). The position of mainstream German media can be described as "pro-Ukrainian" the Ukraine crisis, $52 \%$ of Germans respondents evaluated an EU reaction to Ukraine conflict [4]. In October 2014, 52\% of German respondents positively evaluated sanctions against Russia [4]. This concludes that the analysed media stories had a potentially significant influence on voters who typically support the two major political parties while having a way less influence on AfD supporters and the pro-Russian electorate.

Regarding the support of Belarussian protests, a significant difference compared to the evaluation of Maidan protests in Ukraine was the more indifferent reaction of German officials, which was criticised by some German journalists $[29 ; 30]$. Following this study's results, despite the support of Belarussian opposition and generally a slightly more sympathetic attitude towards the goals anti-Lukashenko protests (as indicated by more frequently utilised human impact and moral values frames), the powerlessness frame was more frequently utilised comparing to articles on Ukrainian protests. This tendency indicates a generally more indifferent stance towards protests in Belarus, which was also clearly visible in German official's approach. There might be a few other consequences of differences in the framing of the two protest movements. In articles on the Belarussian resistance movement, moral values and human impact frames were more frequently utilised than articles on Ukrainian protests. As stated above, this indicates a more empathic attitude towards regular protesters and the goals of the Belarussian oppositional movement. Ukrainian oppositional leaders mainly were described as actors who were in a political conflict with Yanukovych. Negotiations between the opposition and local authorities were sometimes even described as a real deal behind the protests ${ }^{12}$ [31]. In the case of Belarus, oppositional leaders were one of the sources of the human impact frame. Swetlana Tichanowskaja, a candidate, who won the election according to Belarussian

\footnotetext{
${ }^{8}$ Meisner, M. (2018, März 22). Appearance on the propaganda channel Russia Today: How the MDR helped the AfD and Moscow at the same time. URL: https://www.tagesspiegel.de. https://www.tagesspiegel.de/gesellschaft/medien/auftritt-im-propagandasender-russia-today-wie-der-mdrder-afd-und-moskau-zugleich-half/21101090.html [in German]

${ }^{9}$ Bundeswahlleiter, D. (2017). Results Germany - The Federal Returning Officer.

${ }^{10}$ Media credibility survey by 2021. (2021, Mai 10) [in German]

11 Unbalanced? How German media cover the Ukraine conflict. (2014). Deutsche Welle. URL: https://www.dw.com/de/unausgewogen-wie-deutsche-medien-\%C3\%BCber-den-ukraine-konfliktberichten/a-17571572 [in German]

${ }^{12}$ The main actors in the Ukrainian power struggle. (2014a, February 19). Süddeutsche Zeitung. URL: https://www.sueddeutsche.de/politik/regierung-die-wichtigsten-akteure-im-ukrainischen-machtkampfdpa.urn-newsml-dpa-com-20090101-140219-99-02154 [in German]
} 
opposition, had no political experience beforehand. She was hardly ever described as a politician but rather a citizen, a mother, and a wife who lived an everyday life but must fight for freedom because her husband was put into jail due to political reasons [32]. Contrary to a more traditional post-soviet leadership figure of Lukashenko, all the three female oppositional leaders are being associated with a more progressive side of Belarussian society $^{13}$. This kind of representation of Belarussian opposition might have found more support among Germans, who tend to lean toward progressive political views.

Finally, regarding the significant difference in conflict frame utilisation and a more violent character of Ukrainian protests in a later phase of Maidan, there was a definite shift in evaluation of oppositional movement in Ukraine in German media. According to Stephan and Chenoweth, there is an overall tendency that "Potentially sympathetic publics perceive violent militants as having maximalist or extremist goals beyond accommodation, but they perceive non-violent resistance groups as less extreme, thereby enhancing their appeal and facilitating the extraction of concessions through bargaining" [25]. Thus, this framing of protests in Ukraine by German media led to some speculations about the presumably extremist character not only of some Maidan-originated movements such as "Right sector" but even Maidan protests in general ${ }^{14}$, which was brought up by some pro-Russian politicians, who were primarily members either of a right-wing party AfD or a socialist party Die Linke [28].

Conclusion. The study results show that German media adopted a different approach while covering protests in Ukraine and Belarus. A statistically significant difference between the frequency of frames utilised in articles concerning both countries was indicated. News stories analysed in this study appear to have more influence on voters of the two biggest political parties in Germany (CDU and SPD) while having less influence on members of the far-right and socialist political parties and their supporters.

\section{References}

1. Diachuk, N., Svyrydiuk, T., Kryvoruchko, T., Biliuk, I., Levchenko, O. (2021). Frame analysis is one of the effective methods of newspaper discourse studying. Revista Amazonia Investiga, 10 (38), 130-137. https://doi.org/10.34069/ai/2021.38.02.12

2. Molotch, H., Neuman, W.R., Just, M.R., Crigler, A.N. (1992). Common Knowledge: News and the Construction of Political Meaning. University of Chicago Press.

3. Berkowitz, D.A. (2009). Reporters and their sources. In T. Hanitzsch, K. Wahl-Jorgensen, Hrsg. (Eds.), The Handbook of Journalism Studies (International Communication Association Handbook) (pp. 102-115). New York, London: Routledge. URL: http://keralamediaacademy.org/ wp-content/uploads/2015/02/Handbook-of-Journalism-Studies.pdf

4. Bildung, B.F.P. (2015, März 27). Survey: The opinion of Germans on the Ukraine crisis. $b p b$. URL: https://www.bpb.de/203681/umfrage-die-meinung-der-deutschen-ueber-die-ukraine-krise [in German]

\footnotetext{
${ }^{13}$ Women demonstrate against Lukashenko in Minsk. (2020, September 26). Süddeutsche Zeitung. URL: https://www.sueddeutsche.de/politik/demonstrationen-frauen-demonstrieren-in-minsk-gegen-lukaschenkodpa.urn-newsml-dpa-com-20090101-200926-99-715331 [in German]

14 Background: The radical Ukrainian group Right Sector. (2015, September 29). Welt. URL: https://www.welt.de/newsticker/dpa_nt/infoline_nt/thema_nt/article125103098/Die-radikale-ukrainischeGruppe-Rechter-Sektor.html [in German]
} 
5. Bray, M. (2013). Translating Anarchy: The Anarchism of Occupy Wall Street. Zero Books.

6. Gitlin, T. (2003). The Whole World Is Watching: Mass Media in the Making and Unmaking of the New Left. University of California Press.

7. Fourie, P.J. (2010, January). An examination of the value of the concept of the Semiosphere in the study of mass communication: Testing the value and feasibility of a proposed research project. URL: https://www.researchgate.net/publication/277271065_An_examination_of_the_value_of_the_concept_of_t he_Semiosphere_in_the_study_of_mass_communication_Testing_the_value_and_feasibility_of_a_propose d_research_project

8. Chong, D., Druckman, J.N. (2007). Framing Theory. Annual Review of Political Science, 10 (1), 103-126. https://doi.org/10.1146/annurev.polisci.10.072805.103054

9. Goffman, E., Berger, B. (1986). Frame Analysis: An Essay on the Organization of Experience. Northeastern University Press.

10. Reese, S.D., Jr., O.G.H., Grant, A.E. (2003). Framing Public Life. Perspectives on Media and Our Understanding of the Social World. Routledge.

11. Terkildsen, N., Schnell, F. (1997). How Media Frames Move Public Opinion: An Analysis of the Women's Movement. Political Research Quarterly, 50 (4), 879-900. https://doi.org/10.2307/448991

12. Kahneman, D., Tversky, A. (1984). Choices, values, and frames. American Psychologist, 39 (4), 341-350. https://doi.org/10.1037/0003-066x.39.4.341

13. Pan, Z., Kosicki, G. (1993). Framing analysis: An approach to news discourse. Political Communication, 10 (1), 55-75. https://doi.org/10.1080/10584609.1993.9962963

14. McQuail, D. (2002). McQuail's Reader in Mass Communication Theory. SAGE Publications Ltd.

15. Hovland, C.I., Weiss, W. (1951). The Influence of Source Credibility on Communication Effectiveness. Public Opinion Quarterly, 15 (4), 635-650. https://doi.org/10.1086/266350

16. Almalki, S. (2016). Integrating Quantitative and Qualitative Data in Mixed Methods, Research - Challenges and Benefits. Journal of Education and Learning, 5 (3), 288-296. https://doi.org/10.5539/jel.v5n3p288

17. Schoonenboom, J., Johnson, R.B. (2017). How to Construct a Mixed Methods Research Design. KZfSS Kölner Zeitschrift für Soziologie und Sozialpsychologie - Cologne Journal of Sociology and Social Psychology, 69, 107-131. https://doi.org/10.1007/s11577-017-0454-1 [in German]

18. Schoonenboom, J., Johnson, R.B., Froehlich, D.E. (2018). Combining Multiple Purposes of Mixing Within a Mixed Methods Research Design. International journal of multiple research approaches, 10 (1), 271-282. https://doi.org/10.29034/ijmra.v10n1a17

19. Morse, J. (1991). Approaches to Qualitative-Quantitative Methodological Triangulation. Nursing Research, 40 (2), 120-123. https://doi.org/10.1097/00006199-199103000-00014

20. Bryman, A. (2006). Integrating quantitative and qualitative research: how is it done? Qualitative Research, 6 (1), 97-113. https://doi.org/10.1177/1468794106058877

21. Neuendorf, K.A. (2016). The Content Analysis Guidebook. SAGE Publications, Inc.

22. McCrum-Gardner, E. (2008). Which is the correct statistical test to use? British Journal of Oral and Maxillofacial Surgery, 46 (1), 38-41. https://doi.org/10.1016/j.bjoms.2007.09.002

23. Bower, K.M. (2003). When to Use Fisher's Exact Test. Six Sigma Forum Magazine, 2 (4), 35-37.

24. Lee, M.D., Wagenmakers, E. (2014). Bayesian Cognitive Modeling: A Practical Course. Cambridge University Press.

25. Chenoweth, E., Stephan, J. (2011). Why Civil Resistance Works: The Strategic Logic of Non-violent Conflict. Columbia University Press.

26. Arzheimer, K. (2015). The AfD: Finally a Successful Right-Wing Populist Eurosceptic Party for Germany? West European Politics, 38 (3), 535-556. https://doi.org/10.1080/01402382.2015.1004230

27. Schärdel, J. (2016). "A rogue who thinks badly". Zeitschrift für Vergleichende Politikwissenschaft - Journal for Comparative Political Science, 10 (2), 131-163. https://doi.org/10.1007/s12286-016-0301-1 [in German] 
28. Meier-Walser, R. (2016). Foreign policy positions of the "AfD" and the "Die Linke" parties. Argumentation Kompakt. URL: https://www.hss.de/download/publications/Argu_Kompakt_201611_AfD_Linke.pdf [in German]

29. Forbrig, J. (2021, Januar 8). Belarusian calls for help: Germany and Europe lack solidarity and a strategy for a democratic Belarus. Heinrich Boell Foundation. Heinrich-Böll-Stiftung. URL: https://www.boell.de/de/2021/01/08/belarusische-hilferufe-deutschland-und-europa-fehlt-es-solidaritaetund-strategie-fuer?dimension1=ds_belarus [in German]

30. Salzen, C. (2020, August 16). Criticism of the reaction to the Belarus protests: "Germany and the EU are watching". URL: https://www.tagesspiegel.de/politik/kritik-an-reaktion-auf-belarus-protestedeutschland-und-die-eu-schauen-zu/26099826.html [in German]

31. Bidder, B. (2013, December 10). Klitschko and opposition to Yanukovych and oligarchs. Der Spiegel. Hamburg, Germany. URL: https://www.spiegel.de/politik/ausland/ukraine-klitschko-undopposition-gegen-janukowitsch-und-oligarchen-a-937552.html [in German]

32. Brössler, D., Nienhuysen, F. (2020, December 17). Tichanovskaya: "I think we can win until spring". Süddeutsche.de. URL: https://www.sueddeutsche.de/politik/belarus-lukaschenko-oppositionpolitik-tichanowskaja-proteste-1.5145698?reduced=true [in German]

Received on 25.02.21 and updated on 05.05.21 